\title{
A Case of Laryngeal Hemangioma Occurring in the Arytenoid Region
}

\author{
Yu Saito ${ }^{1)}$, Akira Hagiwara ${ }^{12)}$ and Noriko Kobayashi ${ }^{1)}$
}

While hemangioma is a common tumor in the head and neck region, it rarely occurs in the larynx. Herein, we report a case of laryngeal hemangioma that occurred in the arytenoid region. The patient was a 33-year-old woman who presented with the chief complaint of throat discomfort. Endoscopy showed a tumor in the larynx of blue-violet color with an irregular surface, occupying the arytenoid region bilaterally. Bolus of food was confirmed in the right pyriform sinus. CT confirmed the presence of the tumor in the arytenoid region bilaterally. Some calcification was observed within the tumor. On MRI, the tumor was visualized as an iso-intensity on T1-weighted images and as a hyperintensity on T2-weighted images. We performed direct dissection under laryngomicroscopic observation. During the operation, it was difficult to see the entire tumor within the same visual field under the laryngomicroscope. The tumor was diagnosed histopathologically as a cavernous hemangioma. There are several reports of the necessity of an external incision with tracheotomy in cases with giant tumors. Dissection under a laryngomicroscope, without tracheotomy and the attendant dysfunction of vocalization and swallowing, is a better option for the treatment of cavernous hemangioma.

Keywords : larynx, laryngomicroscope, cavernous hemangioma

\section{References}

1) Wada K, Aoki K and Hirabayashi M : Hemangioma of the larynx - a report of two cases-. Pract Otol (Kyoto) Suppl 38: 191-196, 1990.

2) Mulliken JB and Glowacki J : Hemangiomas and vascular malformations in infants and children: a classification based on endothelial characteristics. Plast Reconstr Surg 69: 412-422, 1982.

3）大須賀慶悟，東原大樹，前田 登，他：ISSVA 分類に基 づく頭頸部血管奇形の診療の実際。頭頸部癌 34：393-397, 2008.

4）高橋瑞乃, 齋藤康一郎, 稲垣康治, 他：喉頭腔に嵌頓する 有茎性病変を伴い，治療に難渋した巨大血管腫の 1 症例. 日気管食道会報 61：504-509, 2010.

5）河田了, 兵佐和子, 田中 斉, 他：下咽頭側切開で摘出 した喉頭血管腫症例. 耳鼻・頭頸外科 73：607-610, 2001.

6) Hattori R, Shimizu T, Bhandari A, et al. : Hemangioma of the epiglottis. Pract Otol (Kyoto) 97: 977-981, 2004.

7) Yoshifuku K, Nagano H and Kurono Y : A case of laryngeal hemangioma treated with $\mathrm{CO}_{2}$ laser surgery and sclerotherapy. Pract Otol (Kyoto) 101: 215-220, 2008.

8）伊藤 亭, 西村一雅, 富樫かおり, 他：頸部・顔面の海綿 状血管腫に対する超電導 MRI. 臨放 31：1497-1502, 1986.

9）加地展之, 脇田進一, 川那部岳志, 他 : 血管腫 - 血管奇形 の硬化塞栓療法一硬化療法の安全性と確実性について一. 形成外科 42: 685-694, 1999.

10）平井良治, 牧山 清, 岸 博行, 他: 喉頭血管奇形に対す る直達喉頭鏡下手術. 喉頭 23: 97-100, 2011.

11) Persky MS, Yoo HJ and Berenstein A : Management of vascular malformations of the mandible and maxilla. Laryngoscope 113: 1885-1892, 2003.

12) Black MM and Wilkinson JL : Skin diseases in pregnancy. Princ Pract Obstet Perinatol 2: 1361-1379, 1981.

13) McCausland AM, Hyman C, Winsor T, et al. : Venous distensibility during pregnancy. Am J Obstet Gynecol 81: 472-479, 1961.

14) McCausland AM, Holmes F and Trotter AD Jr : Venous distensibility during the menstrual cycle. Am J Obstet Gynecol 86: 640-643, 1963.
1) Department of Otorhinolaryngology, Kohsei Chuo General Hospital

2) Department of Otorhinolaryngology, Tokyo Medical University
Corresponding Author Address : Yu Saito sysesy20121111117@yahoo.co.jp 
15) Elliott JH, Rankin RN, Inwood MJ, et al. : An arteriovenous malformation in pregnancy: a case of report and review of the literature. Am J Obstet Gynecol 152： 85-88, 1985.

16) Wiegand S, Eivazi B, Karger R, et al. : Surgery in patients with vascular malformations of the head and neck: value of coagulation disorders. Phlebology 24: 38-42, 2009.

17) McRae RD, Gatland DJ, McNab Jones RF, et al. : Malignant transformation in a laryngeal hemangioma. Ann Otol Rhinol Laryngol 99: 562-565, 1990.

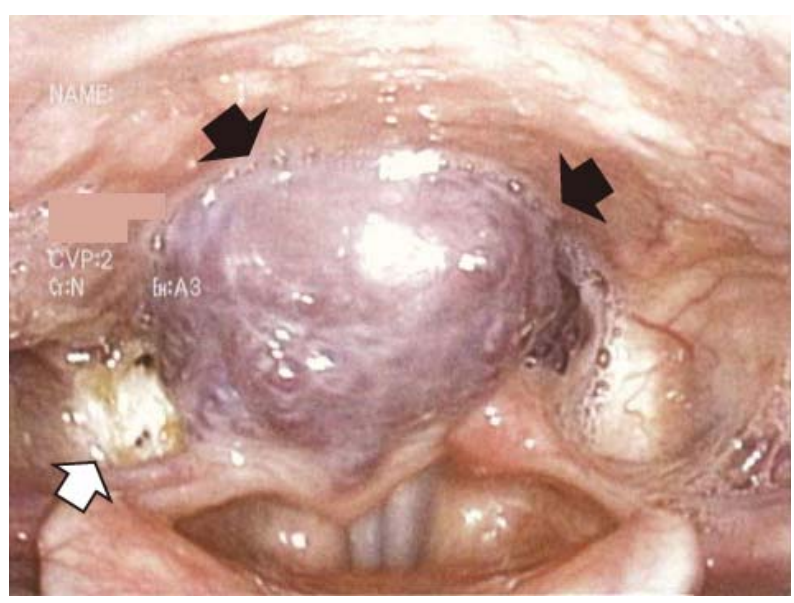

The endoscopic view showing a tumor arising from the two arytenoids (black arrow). Note the food debris in the right pyriform sinus.
18）香取秀明, 石戸谷淳一, 佃守：耳鼻咽喉科領域におけ る難治性疾患 咽頭血管腫. JOHNS 21：1343-1346, 2005.

19）藤島禎弘, 黒田浩之, 天津睦郎：硬化療法が著効した喉頭 血管腫の 1 例. 日気管食道会報 49: 531-535, 1998.

20）鈴木敏弘, 河田了, 村上 泰 : 喉頭側切開および咽頭側 切開で摘出した喉頭血管腫 2 症例. 日気管食道会報 48 : 468-474, 1997.

21）吉野清高：食道静脈瘤の内視鏡的硬化療法に用いられる硬 化剂の作用と安全性. 医薬ジャーナル 22：89-94, 1986.

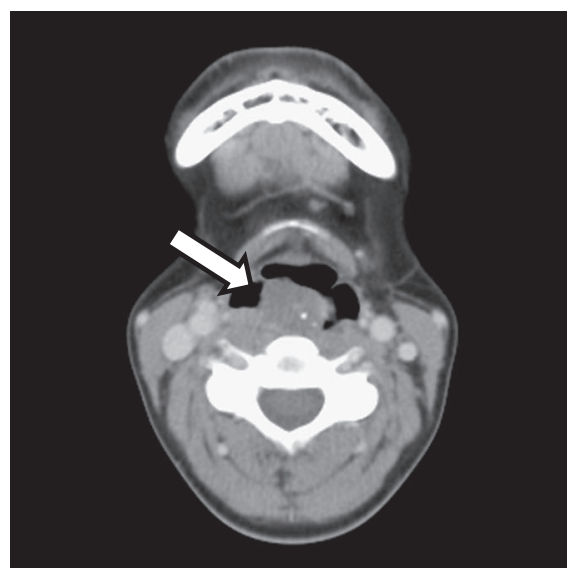

CT scan of a partially enhanced tumor (arrow) with calcification.

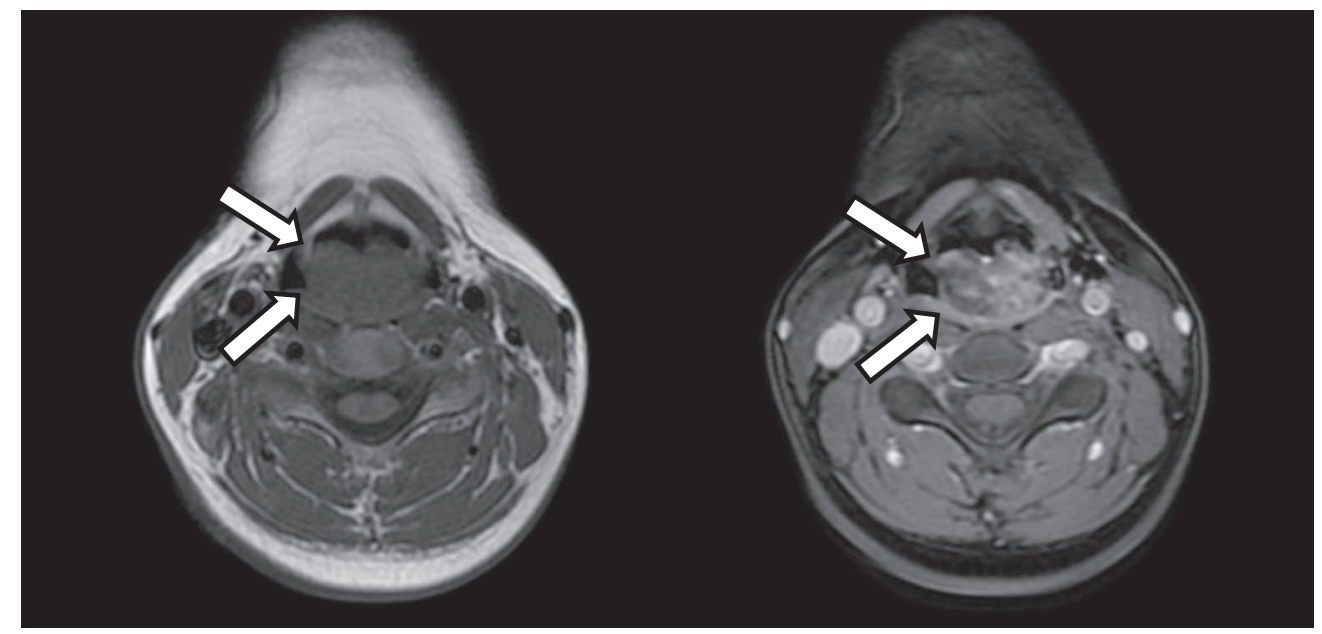

T1-weighted MRI showing an iso-intense tumor (left). The tumor was heterogeneously enhanced after the administration of gadolinium (right). 